\title{
ETELÄISTÄ SAAMENTUTKIMUSTA
}

\author{
Karina Lukin
}

Saamentutkimuksen sisällä on totuttu rakentamaan vähintäänkin vaikeaa, ellei jopa vastakohtaista suhdetta niin sanottuun lappologiaan. Lappologiaa kuvaillaan ulkopuolisen ja vallassa olleen kulttuurin näkökulmista tehdyksi tutkimukseksi, kun taas saamentutkimusta pidetään saamelaisuuden sisältä päin tehtynä, ryhmää enemmän hyödyttävänä tutkimussuuntauksena. (Esim. The Saami 2005, 356-357.) Suomalaisen Kirjallisuuden Seura on julkaissut varsin lyhyen ajan sisällä lukuisia saamelaisuutta käsitteleviä kirjoja, jotka asettivat saamentutkimusta sivusta seuranneen tutkijan kiusaukseen: halusin lukea, millaista saamentutkimus on tänään. Asettuuko se edelleen vanhan ja uuden, ulko- ja sisänäkökulmien vastakkainasetteluille? Pohditaanko näitä asetelmia saamentutkimuksessa?

Katsauksen sysääjistä ensimmäisenä on mainittava helsinkiläisten saamentutkijoiden toimittama, oppikirjakäyttöön tarkoitettu artikkelikokoelma Saamentutkimus tänään (2011), joka on jatkoa 20 vuotta sitten ilmestyneelle Johdatus saamentutkimukseen -kirjalle (1994). Vuoden sisällä tämän oppikirjan ilmestymisestä Kalevalaseura julkaisi toisen saamelaisia käsittelevän suomenkielisen, kulttuuritieteellisiä artikkeleita sisältävän kokoelman nimeltä Saamenmaa (2012). Näiden teosten lisäksi pohdin katsauksessani Veli-Pekka Lehtolan palkitun teoksen Saamelaiset suomalaiset lähtökohtia ja ratkaisuja, Risto Pulkkisen suomentamien Lars Levi Laestadiuksen mytologiafragmenttien suhdetta saamentutkimukseen sekä joidenkin viimeaikaisten suomenkielisten väitöskirjojen tuottamia mielikuvia (Enges 2012; Kylli 2012; Sarivaara 2013). Peilaan suomenkielisiä teoksia Kuolan niemimaata käsittelevään tutkimukseen Bridging 
Divides, jossa uuden ja vanhan tutkimuksen rajaviiva ei ole noussut keskustelun aiheeksi (Overland \& Berg-Nordlie 2012).

Lukiessani yllä mainittuja teoksia aloin ymmärtää, että Helsingissä julkaistujen kirjojen pohjalta en voisi saavuttaa relevanttia tai oikeudenmukaista kuvaa saamentutkimuksen nykytilasta. Jokainen lukemani tutkimus, niin monografia kuin artikkelikin, viittasi lukemattomiin pohjoisessa julkaistuihin tutkimuksiin, joita on pelkästään Suomessa ilmestynyt usealla paikkakunnalla. Ensimmäinen pintapuolinen päätelmä onkin, että saamentutkimusta ei tehdä enää pääkaupunkiseudulta käsin matkaten tai helsinkiläisissä nojatuoleissa, mikä on ilahduttavaa. Lappologiasta ei kenties enää voida puhua. Toinen päätelmä oli vähemmän tyydyttävä: jouduin nöyrtymään hyvin laajan julkaisumateriaalin edessä ja tunnustamaan, että lukemieni kirjojen pohjalta voi tehdä päätelmiä ainoastaan siitä, minkälaista mielikuvaa pääkaupunkiseudun kustantaja saamelaisista luo, Kuolan niemimaata käsittelevää kirjaa sekä Engesin ja Sarivaaran väitöskirjoja lukuun ottamatta. Niinpä tämän katsauksen keskiössä oleva saamentutkimus on varsin valikoitunutta, ja olen täydentänyt sitä ennemminkin julkisen keskustelun ja oman, itään suuntautuvan mielenkiintoni varassa kuin systemaattisesti.

\section{JÄLKIKOLONIALISTINEN SAAMENTUTKIMUS JA KOLONIALISMIN MAHDOLLI- SUUDET}

Saamentutkimus tänään -kirjassa (Seurujärvi-Kari, Halinen ja Pulkkinen (toim.) 2011) Irja Seurujärvi-Kari asettaa saamentutkimuksen alkuperäiskansatutkimuksen kontekstiin ja korostaa saamelaisten asemaa yhtenä maailman alkuperäiskansoista. Tekstissä toistuvat kolonialismin, alistamisen ja väärintulkintojen historiat ja tietoisuus näiden ongelmien globaalista ilmenemisestä. Seurujärvi-Kari muun muassa viittaa alkuperäiskansatutkimuksessa vaikutusvaltaiseen Linda Tuhiwai Smithin teokseen Decolonizing Methodologies (1999) ja toistaa usein kuultuja vaatimuksia vallitsevien teorioiden dekolonisoimisesta ja uusien alkuperäiskansametodologioiden rakentamisesta. Vastaavalla äänellä kirjoittaa Tero Mustonen, joka on rakentanut Saamenmaa-kirjassa (Lehtola, Piela ja Snellman (toim.) 2012) julkaistussa artikkelissaan uuden tulkintakehyksen saamentutkimukselle. Mustosen viisikohtaisessa listassa todetaan, että

[...] saamelaiset itse tietävät parhaiten, miten heidän tietoaan tulee tulkita (ja tutkia) [...], vain saamelaisilla on oikeus määritellä, mitä saamelainen tieto on ja miten sitä käsitellään [...], saamelaisten suullinen perinnetieto tulisi huomioida kirjallisten lähteiden vertaisena lähteenä tieteellisessä tutkimuksessa [...], saamentutkimuksen pääasiallinen kommunikaatiokieli tulisi olla 
saame [sic!] [...], ulkopuolisten tutkijoiden tulisi asemoida saamelaiset tutkimuksessaan kanssatutkijoiksi. (Mustonen 2012, 261.)

Tällainen saamentutkimus haastaa etnografisen tutkimusotteen - eikä pelkästään entistä lappologiaa vaan myös nykyisen tutkimuksen, jossa esimerkiksi filosofi Inkeri Koskisen mukaan
tutkijat pitävät eri tietokäytännöt selvästi erossa toisistaan. Akateemiset tietokäytännöt ja akateeminen keskustelu ovat oma, erillinen alueensa, jolle tutkittavien tietokäytäntöjä ei tuo- da muuten kuin tutkimuskohteina. [...] Tieteellistä argumentaa- tiota ei siis perusteta esimerkiksi melanesialaiselle näkemyksel- le, että jos jonkun tiedetyn asian kertoo, sen arvo tietona kato- aa. Tai episteemisen auktoriteetin ei (toivottavasti) katsota määräytyvän tutkijan iän perusteella, vaikka monien tutkittavi- en parissa niin ajatellaankin. (Koskinen 2012, 200.)

Lukemieni kirjojen perusteella alkuperäiskansatutkimuksen radikaali episteeminen kanta ei ole saavuttanut suosiota saamentutkijoiden parissa, mutta sen vaikutuksia saattaa tutkimuksessa nähdä - ellei niitä halua lukea yleisen, 1980- ja -90-lukujen etnografisen episteemisen kriisin tuloksiksi. Kyse onkin yhtäältä siitä, että radikaalit alkuperäiskansatutkijat taistelevat lappologiaa tai muita menneitä tutkimusperinteitä vastaan, vaikka nämä eivät enää nauti suosiota etnografienkaan piirissä, mihin ovat osittain syynä esimerkiksi juuri Smithin kirjan vaikutus mutta myös laajemmat etnografiset keskustelut. Toisaalta joidenkin tutkijoiden tekemä rinnastus lappologian ja kolonialismin välillä on ongelmallinen, ja tästä syystä eräät alkuperäiskansatutkimuksen lähtökohdatkin asettuvat kyseenalaisiksi. Veli-Pekka Lehtola käy taiten keskustelua kolonialismikeskustelujen soveltamisen mahdollisuudesta saamentutkimuksessa. Hänen mukaansa kolonialismin käsite on edelleen hyödyllinen väline, mutta sitä ei pidä käyttää uhriasetelmien luomiseen: tutkijoiden on pyrittävä hienosyiseen aineistojen tulkintaan, jossa tulevat esille saamelaisten ja suomalaisten monitahoiset suhteet. (Lehtola 2012, 15-17.)

Lehtola purkaa kirjassaan Saamelaiset suomalaiset kolonialistisia asetelmia näistä lähtökohdista, esimerkiksi valottaessaan lappologisten aineistojen syntyjä. Lehtola käy tarkalla otteella läpi suomalaisten ja saamelaisten kohtaamisia 1800-luvun lopulta 1900-luvun puoliväliin. Lehtolan analyysissä heijastuvat niin suomalaisten virkamiesten, pappien kuin tutkijoidenkin ja paikallisten saamelaisten välinen jännite, molemminpuolinen arvostuksen puute tai arvonannon hakeminen. Jos suomalaiset pitivätkin saamelaisten elintapoja ja osaamista lähtökohtaisesti huonompina, saamelaiset kertoivat suomalaisten "herrojen" statusmerkeistä ja koppavuudesta koomisia tarinoita. Lehtola on kaivanut esiin tällaisia kahdesta näkökulmasta samoja tapahtumia valottavia tekstejä ja analysoi niitä maltilla. Suomalaisten kirjoittamat tekstit eivät olekaan enää ainoastaan 
lähdekritiikin kohteita ja tutkimusaineistoja, vaan niiden rinnalle tarjotaan täysin uusi näkökulma. Enimmäkseen Lehtolan teemat kertovat yrityksistä kohdata ja taiteilla erilaisuuden kanssa, mutta myös näkökulmista, jotka eivät koskaan kohdanneet. Tällainen on esimerkiksi sivun 76 karttapari, jossa virkamiehen kartta kuvaa Lapin kihlakuntaa "syrjäisenä kolkkana, johon ei mennyt maanteitäkään". Toinen, pohjoisen kulkuteitä kuvaava kartta osoittaa paikallisten reittien suuntautumisen etelän sijasta Jäämerelle.

Lehtolan otetta ja kirjoitustapaa on helppo ihailla. Virallisen historian ja virallisten dokumenttien sekä paikallisten tulkintojen ja tapojen vertailun taustalla on massiivinen työ niin aineiston hankinnassa kuin sen haltuunotossakin. Erityisen herkullisia ja avartavia ovat kohdat, joissa viranomaisten itse kertoma ja esittämä mielikuva hierarkiasta kääntyy paikallistulkinnoissa päälaelleen (esim. s. 60-61.) Mutta Lehtola ei pura vastakkainasettelua ainoastaan inversion avulla, vaan hän tekee sen myös tuomalla esiin erilaisten tapahtumien ja niiden ketjujen moniulotteisuuden. Tässä hän ei jätä välillä pienintäkään kiveä kääntämättä. Hyvä esimerkki on kertomus, jonka Lehtola tarjoaa Martti Walleniuksen ja Moskun edesottamuksista Kuolan ja Suomen itärajalla ensimmäisen maailmansodan jälkimainingeissa. Kerrottuaan oman versionsa Lehtola viittaa niin sompiolaisiin kuin kolttien omiinkin kertomuksiin tapahtumista, mutta myös Walleniuksen itse kirjoittamaan tekstiin (s. 167). Itse Lehtola toteaa, että "tapauksen taustalla on monimutkainen vyyhti paikallisiin suhteisiin ja elinkeinoihin liittyviä ristiriitoja sekä toisiinsa sekoittuvia poliittisia ja etnisiä asenteita" (s. 165), minkä hänen analyysinsa hyvin osoittaa.

\section{IDENTITEETIN VETO- JA TYÖNTÖVOIMAT}

Lappologian kritiikki ja vaatimukset uudenlaisesta tutkimuksesta on syytä nähdä saamelaisen renessanssin tai etnisen heräämisen jatkumossa. VeliPekka Lehtolan ja Anni-Siiri Länsmanin artikkeli Saamenmaa-kokoelmassa valottaa hienosti tämän liikkeen syntyä ja kehittymistä. Artikkelin lopussa kuvailtu keskustelu saamelaisten identiteetin mahdollisista sisällöistä, stereotypioista, saamelaisuuden keskustasta ja marginaalista tarjoavat loistavaa reflektiota saamelaiseliitin moninaisista toiminnan kentistä sekä niistä kiistoista ja ratkaisuista, joita toiminnassa elää. Tähän keskusteluun liittyy myös Nika Potinkaran artikkeli, jossa osoitetaan kahden saamelaismuseon, Siidan ja Ájtten, voivan

tulkita esittävän saamelaisuutta jossain määrin stereotyyppises-

ti. [...] [K]ota, poro ja noitarumpu näkyvät molempien museoi- 
den näyttelyissä, eikä esimerkiksi kaupunkisaamelaisuutta tai saamelaisyhteisöjen sisäisiä eroja tuoda esiin. (Potinkara 2012, 178.)

Syvempää näkökulmaa saamelaisuuden keskustaan ja marginaaliin tarjoaa Erika Sarivaaran kohua herättänyt väitöskirja, joka koskettaa niin kutsuttuja statuksettomia saamelaisia, toisin sanoen henkilöitä, jotka polveutuvat saamelaissuvusta mutta joita ei ole merkitty saamelaiskäräjien vaaliluetteloon. Tutkimuksen teema on tulenarka siitä syystä, että vaikka saamelaiskäräjien vaaliluettelo on mahdollista nähdä "vain" poliittisen identiteetin ilmaisijana, sillä on juuri vallan ja kollektiivisen tunnustuksen vuoksi sekä käytännön että symbolista merkitystä. Vaaliluetteloon ei taas haluta suomalaisia, minkä vuoksi saamelaiskäräjät on pitänyt kiinni tiukoista lain tulkinnoista. Käytännössä Sarivaaran tutkimus keskittyy henkilöihin, jotka ovat olleet mukana elvyttämässä saamen kieltä eli opetelleet vanhempiensa tai isovanhempiensa hylkäämän kielen aikuisiällään. He kokevat saamelaisuuden positiivisena toisin kuin vielä omat vanhempansa, mutta saamelaisyhteisö ei ole valmis ottamaan heitä osaksi etnistä yhteisöä virallisesti, eikä osittain arkielämässäkään.

Sarivaara tarjoaa mainion johdannon saamelaisuuden moninaisuuteen ja pirstaleisuuteen esittelemällä saamen kieliä, saamelaisten asuttamia maita, saamelaisten elinkeinojen moninaisuutta ja käsitteitä, joilla saamelaisuuden kenttää on koetettu ottaa haltuun. Sellaiset käsitteet kuin metsä-, tunturi-, joki- ja merisaamelainen, ulkosaamelainen, citysaamelainen, saamensukuinen, uussaamelainen ja suomea puhuvat saamelaiset saavat tekstissä selityksensä ja avaavat niin menneiden kuin nykysukupolvienkin vaihtelevia kulttuurisia ja yhteiskunnallisia elinkenttiä. (Sarivaara 2012, 28-32.) Sarivaara esittelee ja erittelee haastatteluissa nousseita teemoja, kuten haastateltavien ylisukupolvista paikantumista ja etnostressiä, joka syntyy, kun ei pysty asettumaan etnisen identiteetin vaatimuksiin, pelkoa esittää saamelaisuutta julkisesti, kielenvalintaan kussakin kontekstissa ja kielen opiskeluun vaikuttaneita tekijöitä. Nimenomaan tutkimuksen tieteellisen laadun arvioiminen on aiheuttanut paljon kohua, enkä katsauksessani ota tähän keskusteluun kantaa. Sarivaaran tutkimus edustaa kriittistä kulttuurin- ja yhteiskunnan tutkimusta, ja sen yhtenä tarkoituksena on nimenomaan ollut herättää keskustelua ja vaikuttaa yhteiskuntaan. Tutkimus on onnistunut nostamaan näkyvästi esiin saamelaisyhteisön sisäiset jännitteet ja pohjoisen historian monitahoiset seuraukset.

Jos etnopolitiikka on kiivasta Suomessa, niin sellaista saamelaispolitiikka on ollut myös Neuvostoliiton hajoamisen jälkeen Kuolan niemimaalla. Indra Overlandin ja Mikkel Berg-Nordlien Bridging Divides (2012), joka luo katsauksen Kuolan saamelaisten etnopolitiikkaan, tarjoaa kiinnostavan näkökulman pohjoismaisen saamelaisuuden itäiseen marginaaliin. Kirjoit- 
tajat tuovat esille monia arkaluontoisia asioita, jotka liittyvät Kuolan saamelaisten sisäiseen stratifikaatioon sekä idän ja lännen saamelaisten keskinäisiin, usein ongelmallisiin suhteisiin. Teoksessa kartoitetaan taitavasti ja historiallisesti kontekstualisoiden niitä raja-aitoja, jotka vallitsevat maaseudun ja kaupungin, kouluttamattomien ja hyvin koulutettujen, saamea osaavien ja saamea taitamattomien välillä. Nämä rajaaidat ovat tuttuja Venäjän pohjoisiin kansoihin perehtyneille inmisille, sillä ne ovat syntyneet neuvostoaikaisen alkuperäiskansapolitiikan seurauksena. Avartavia ovat myös kokonaisuuden monimutkaisuutta avaavat esimerkit. Näistä käy ilmi, miten Kuolan saamelaisten kouluttaminen lännessä ruokkii yhtäältä uhanalaisen kildininsaamen hylkäämistä pohjoissaamen hyväksi, mutta avaa toisaalta itäsaamelaiset näkemään etnisyytensä modernina ja arkipäiväisenä, eikä perinteisenä ja museoitavana toisin kuin Herzenin pedagogisen instituutin kouluttamat paikalliset opettajat valitettavasti edelleenkin ajattelevat.

\section{MONITIETEINEN SAAMENTUTKIMUS JA KANSANOMAINEN USKONTO}

Yksi saamentutkimuksen peruslähtökohdista on sen monitieteisyys tai tieteidenvälisyys. Kun monitieteisyys tarkoittaa eri tieteiden yhtä aihealuetta kohtaan suuntaamaa kiinnostusta, tieteidenvälisyydessä pyritään yhdistämään eri tieteenalojen tarjoamia näkökulmia. Lukemieni kirjojen pohjalta saamentutkimus näyttäytyy suhteellisen perinteisten tieteenalojen joukkiona, joka kokoaa pohjoisesta kiinnostuneita tutkijoita saman varjon alle - kyse on siis ennemminkin monitieteisyydestä. Tieto tuntuu lohkoutuvan länsimaiselle ajattelulle tyypillisellä tavalla esimerkiksi Saamentutkimus tänään -kirjassa. Lisäksi juuri tässä kirjassa lappologisella perinteellä on hieman yllättäen osansa. Kirjan johdannossa toimittajat toteavatkin, että kirjan tarkoitus on antaa havainnollinen "kuva siitä, kuinka eri tieteenalat voivat antaa panoksensa saamelaisia koskevaan tutkimukseen" (Seurujärvi-Kari et al. 2011, 8). Teos rakentuu varsin perinteiselle tieteenalajaottelulle ja tarjoaa erityisesti menneisyyteen suuntautuneita tekstejä kielitieteen, arkeologian, kansanomaisen uskonnon, kirjallisuuden ja etnologian aloilta. Toki kirjassa on ajankohtaisiakin artikkeleita, jotka koskettavat alkuperäiskansatutkimusta, saamelaisten käsitöitä ja lainsäädäntöä. Eri tieteenalojen näkökulmat eivät kuitenkaan juurikaan kohtaa, vaan eri alojen perustietojen yhteensovittaminen jää lukijan tehtäväksi.

Saamentutkimus tänään on tarkoitettu oppikirjaksi, millä voidaan perustella sen hajanaisuutta ja kenties perinteisyyttäkin. Tästä poiketen Saamenmaa-artikkelikokoelma tarjoaa paljon uutta tietoa ja uusia näke- 
myksiä saamelaisten historiasta, kielellisistä käytänteistä ja kulttuurista mutta myös nykypäivän yhteiskunnallisista keskusteluista. Artikkeleita leimaa monenlaisten raja-aitojen ylittäminen: Taarna Valtonen rakentaa kehystä paikannimien ja kulttuurisen tiedon analysoimisen mahdollisuuksille, Marko Jouste yhdistelee laulukuvauksia ja -muistiinpanoja kulttuurisiin kuvauksiin, Anna-Liisa Väyrynen kokoaa mielikuvaa veden alle jääneistä kodeista suullisen ja materiaalisen muistiaineiston avulla ja Ritva Kylli hahmottaa saamelaisten uskonnollisuutta historiallisista aineistoista. Tällaiset ylitykset ovat selvästi vaatineet paljon työtä, mutta ne tuottavat myös näyttäviä tuloksia.

Ritva Kyllin artikkeli pohjautuu hänen väitöskirjaansa (2012), joka tarjoaa kattavan esittelyn saamelaisten uskonnollisuudesta 1600-luvulta 1900luvulle asti. Mikrohistoriallisessa tutkimuksessaan Kylli yltää syvälle ja lavealle. Tällainen kattava ja moniulotteinen esitys asettuu vääjäämättä vastakohtaiseksi esimerkiksi Saamentutkimus tänään -teoksesta löytyvän lappologisen esityksen kanssa. Vaikka jäin folkloristina kaipaamaan juuri suullisen historian ja folkloren hyödyntämistä, ymmärrän hyvin, että näiden aineistojen analysoinnin vaatima metodinen asiantuntijuus ei voi mahtua jokahistorioitsijan taitopakkiin. Folkloristille olisikin vielä paljon työtä vanhojen saamelaisten aineistojen parissa!

Yhden esimerkin tällaisesta työstä tarjoaa Pasi Engesin väitöskirja (2012), joka perustuu sekä uuteen että vanhaan materiaaliin. "Minä melkein uskoin" -tutkimuksen aineisto pohjautuu Turun yliopistossa 1960-luvulla aloitettuun Talvadas-projektiin, jonka tarkoituksena on ollut soveltaa aikanaan uusia antropologisia menetelmiä ja kartoittaa yhden yhteisön koko perinne. Projekti on yksi pitkäaikaisimmista kenttätyöprojekteista Suomessa, mutta kokonaista perinnekorpusta siinäkään tuskin onnistuttiin keräämään. Aineisto heijastelee todennäköisesti perinteen muutosta, mutta se tuo esiin myös folkloristiikan paradigmojen muutoksia: vaikka lappologiasta ei enää 1960-luvulla voidakaan puhua, Engesin tutkimus näyttää selkeästi esimerkiksi sen, miten aineistonkeruun positivistinen henki on 2000-luvulle tultaessa murentunut. Engesin tulkinnat haastattelutilanteista ja kerronnan tuottamisesta osoittavat samaan suuntaan kuin Lehtolankin: tutkijoiden lähtökohtien, saamelaisten näistä tekemien tulkintojen ja heidän omaehtoisen kommunikaationsa tuottamiin "kohtaamisiin".

Saamelaisten uskonnollisuudesta puhuttaessa on mahdotonta syrjäyttää Lars Levi Laestadiuksen suurteosta saamelaisten mytologiasta. Risto Pulkkisen suomentama Lappalaisen mytologian katkelmia sisältää uusia käsikirjoituslöydöksiä, joiden mutkaisia teitä Pulkkinen ja Juha Pentikäinen selvittelevät esipuheessaan. Muutoin esipuhe on harmittavan niukka. Siinä asetetaan Laestadius aate- ja tieteenhistorialliseen taustaansa ja koroste- 
taan hänen saamelaisuuttaan. Kun Laestadius mytologiassaan tuon tuostakin kritisoi ulkopuolisten tekemiä johtopäätöksiä ja tarjoaa omiaan, parempaan paikallistuntemukseen perustuvia, syntyy kiusaus kutsua Laestadiusta ensimmäiseksi saamentutkijaksi. Anakronistiset tulkinnat voi kenties unohtaa, mutta olisin mieluusti nähnyt Laestadiuksen asetettavan aikansa muiden mytologien joukkoon: siinä joukossa (vielä) eli halu tavoittaa kansan tuottaman perinteen sisäinen mieli ja sen yhteys muiden kansojen tuottamaan perinteeseen.

\section{MITEN ULKOPUOLISET AJATTELEVAT?}

Saamentutkimus on kuuma kenttä, mutta lukemissani kirjoissa kuumuus tuntuu oikeastaan vain Sarivaaran väitöskirjassa ja Bridging Divides teoksessa. Aiemmin siteeraamani Inkeri Koskisen artikkeli pohtii ymmärtämistä alkuperäiskansatutkimuksessa. Hän kuvaa artikkelin alussa alkuperäiskansatutkimuksen ja "muun kulttuurien tutkimuksen" ongelmallista suhdetta:
Kärjistäen voisi sanoa, että muut kulttuurien tutkijat vaikuttavat jossain määrin haluttomilta käymään kriittistä ja rakentavaa keskustelua alkuperäiskansatutkijoiden kanssa. Konferens- siesitelmiä saattaa seurata kohtelias hiljaisuus, vaikka sama asia tavanomaisemman kulttuurientutkijan esittämänä herättäi- si kriittistä keskustelua. Toisaalta kun muut kulttuurientutkijat joutuvat esittämään kritiikkiä, esimerkiksi kirjoittaessaan refe- ree-lausuntoja, osoittautuu, että he usein pitävät monia alkupe- räiskansatutkimuksessa laajalti hyväksyttyjä kantoja erittäin kyseenalaisina. (Koskinen 2012, 196.)

Käytännössä kohteliaan tahi tyrmistyneen hiljaisuuden aiheuttanee tutkijoiden usein aiemmin kuulema tai lukema näkemys saamelaisten lähtökohtaisesti määräävästä roolista tutkimuksessa ja kansanomaisten aineistojen samastaminen tutkimustiedon kanssa. Konferensseissa sen sijaan törmää Koskisen kuvaamiin tilanteisiin silloin tällöin. Mustosen pamflettia lukuun ottamatta tämänkaltaisia kantoja ei tullut esiin lukemassani kirjallisuudessa. Välillisesti ulkopuolisten tekemän tutkimuksen väheksyminen on luettavissa myös tässä katsauksessa käsitellyistä kirjoista: se näkyy esimerkiksi ulkopuolisten tekemän kenttätyötutkimuksen vähäisenä määränä.

Yksi syy ulkopuolisten hiljaisuuteen on myös tämänkin keskustelun pituus: sitä on käyty jo pari vuosikymmentä, ellei kauemmin. Esimerkiksi Gananath Obeysekeren (1992) ja Marshall Sahlinsin (1995) 1990-Iuvun alussa käymä keskustelu natiivien näkökulman saavuttamisen mahdolli- 
suuksista on oiva esimerkki siitä, että oman ja toisen rajaa on vedetty ja vedetään jälkikolonialistisessa maailmassa edelleen.

Koskisen maltillinen tulkinta alkuperäiskansatutkimuksen radikaalista episteemisestä kannasta on se, että kanta haastaa etnografian. Voidaan esittää myös voimakkaampi näkemys, jonka mukaan esimerkiksi se seikka, ettei ulkopuolisten nähdä voivan perustella tutkimuksen lähtökohtia, kyseenalaistaa länsimaisen etnografisen perinteen laajasti. Vaikka tutkimusperinteellä on kaikkialla omat mustat historiansa, pitää etnografinen perinne nähdä Sahlinsin (esim. 1995, 118) tavoin ennen kaikkea yrityksenä ymmärtää toisten aika- ja paikkasidonnaisia ajattelun tapoja ja ravistella itsestään selviä kategorioita, logiikkaa ja arkiajattelua.

Etelässä 2010-luvun alussa julkaistun saamentutkimuksen perusteella tieteenalan keskustelut käydään edelleen länsimaisen tieteen viitekehyksissä ja ulkopuolisten, ei-saamelaisten tutkijoiden kanssa, heidän keräämiensä aineistojen pohjalta. Toivoa saattaa, että tämä johtopäätös ei johdu katsauksen eteläkeskeisestä lähtökohdasta, vaan laajemmasta halusta akateemiseen vuorovaikutukseen.

KIRJALLISUUS

Anttonen, Marjut 1999: Etnopolitiikkaa Ruijassa. Suomalaislähtöisen väestön identiteetin politisoituminen 1990-luvulla. Helsinki: SKS.

Enges, Pasi 2012: "Minä melkein uskon". Yliluonnollinen ja sen kohtaaminen tenonsaamelaisessa uskomusperinteessä. Turku: Turun yliopisto. [online]. $<$ http://www.doria.fi/bitstream/handle/10024/76830/Enges.pdf?se quence $=1>[1.2 .2014$. $]$

Koskinen, Inkeri 2012: Ymmärtäminen tämän päivän alkuperäiskansatutkimuksessa. - Viljanen, Valtteri, Siipi, Helena, Sintonen, Matti (toim.), Ymmärrys. Turku: Käyttäytymistieteiden ja filosofian laitos, Turun yliopisto. 196-201.

Kulonen, Ulla-Maija, Seurujärvi-Kari, Irja \& Pulkkinen, Risto (toim.) 2005: The Saami. A Cultural Encyclopaedia. Helsinki: SKS.

Kylli, Ritva 2012: Saamelaisten kaksi kääntymystä. Uskonnon muuttuminen Utsjoen ja Enontekiön lapinmailla 1602-1905. Helsinki: SKS.

Laestadius, Lars Levi 2011: Lappalaisten mytologian katkelmia. Juha Pentikäinen ja Risto Pulkkinen (toim.). Helsinki: SKS.

Lehtola, Veli-Pekka 2012: Saamelaiset suomalaiset - kohtaamisia 1896-1953. Helsinki: SKS. 
Lehtola, Veli-Pekka, Piela, Ulla ja Snellman, Hanna (toim.) 2012: Saamenmaa. Kulttuuritieteellisiä näkökulmia. Helsinki: SKS.

Obeyesekere, Gananath 1992: The apotheosis of Captain Cook: European mythmaking in the Pacific. Princeton (NJ): Princeton University Press.

Sahlins, Marshall 1995: How "natives" think: about captain Cook, for example. Chicago: University of Chicago Press.

Sarivaara, Erika Katjaana 2012: Statuksettomat saamelaiset. Paikantumisia saamelaisuuden rajoilla. Rovaniemi: Lapin yliopisto. [online]. $\quad<$ http://brage.bibsys.no/samall/bitstream/URN:NBN:nobibsys_brage_30768/1/erikanettiversio18 6.pdf> [1.2.2014.]

Seurujärvi-Kari, Irja, Halinen, Petri ja Pulkkinen, Risto (toim.) 2011: Saamentutkimus tänään. Helsinki: SKS.

Smith, Linda Tuhiwai 1999: Decolonizing Methodologies. Research and Indigenous Peoples. London: Zed Books; Dunedin: University of Otago Press.

FT Karina Lukin on tutkinut nenetsejä ja perehtynyt suomalaisten perinnetieteiden historiaan. 